\title{
Pemanfaatan Permainan Tradisional Dalam Pencapaian Indikator Pembelajaran
}

\author{
Ilham 1 , Muhammad Ali ${ }^{2}$, Endarman Syaputra ${ }^{3}$, Hendri Munar ${ }^{4}$ \\ ${ }^{1,2,3,4}$ Fakultas Ilmu Keolahragaan Universitas Jambi \\ 1ilham_bugis@unja.ac.id \\ 2ali_fik@yahoo.co.id \\ 3endarman@unja.ac.id \\ 4hendri_munar@unja.ac.id
}

\begin{abstract}
ABSTRAK
Tujuan yang ingin dicapai dalam kegiatan ini adalah untuk memberikan pemahaman kepada guru penjas perlunya melakukan pembelajaran penjas dalam bentuk bermain untuk pencapaian indicator pembelajaran. Berdasarkan tujuan di atas maka yang menjadi target dan luaran yang diharapkan adalah : 1) Guru penjas dapat mengetahui berbagai bentuk permainan tradisional yang dapat digunakan untuk pencapaian indicator pembelajaran penjas. 2) Guru penjas dapat melakukan pembelajaran penjas dengan menggunakan permainan tradisional untuk pencapaian indicator pembelajaran penjas. Teknik yang digunakan dalam pelaksanaan ini adalah melakukan penyuluhan kepada guru-guru penjas yang berada di wilayah Kecamatan Muara Sabak Barat, Sabak Timur, Geragai Dan Kecamatan Dendang yang berjumlah kurang lebih 71 orang, kegiatan ini bekerjasama dengan SMA Negeri 5 dan SMA Negeri 8 Tanjung Jabung Timur.Kesimpulan pelaksanaan pengabdian ini yaitu : (1) Dalam upaya pencapaian indicator pembelajaran atletika dapat dilakukan dengan menggunakan metode permainan tradisional. (2) Pemanfaatan permainan tradisional dalam upayah pencapaian indicator pembelajara belum dilakukan oleh para guruh Penjas Orkes di Kabupaten Tanjung Jabung Timur. (3) Pemanfaatan permainan tradisional dalam upayah pencapaian indicator pembelajara harus dirancang sedemikian rupa sehingga sesuai dengan materi pembelajaran.
\end{abstract}

Kata Kunci : Indikator pembelajaran, permainan tradisional, Pendidikan Jasmani

\section{PENDAHULUAN}

Didalam pembelajaran pendidikan jasmani anak dilatih untuk mengembangkan kemampuan gerak, kemampuan gerak yang dimiliki nantinya dapat dikembangkan sesuai bakat yang ada pada anak. Oleh karena itu, seorang guru harus bisa mengembangkan berbagai macam materi pembelajaran penjas yang bisa membuat siswa bergerak dan melatih kemampuan gerak, karena anak memang dalam masa usia sekolah sebaiknya diberikan gerakan multilateral yang dapat mengembangkan semua unsur fisik yang ada pada anak, tidak memberikan latihan khusus kepada anak yang hanya mengembangkan sebagian kemampuan motoriknya saja, seperti bermain bola, hanya mengembangkan kemampuan keterampilan kakinya saja.

Anak dalam masa sekolah tergolong masih senang bermain karena dunia anak adalah dunia bermain oleh karena itu diusahakan setiap materi pembelajaran penjas yang akan diberikan haruslah mempunyai unsur permainan yang sifatnya menyenangkan, tetapi tetap tidak meninggalkan materi pokok tentang apa yang ingin dicapai dalam indicator pembelajaran. Dengan terciptanya rasa senang dan gembira ketika belajar pendidikan jasmani, maka dengan sendirinya akan timbul motivasi dalam diri anak untuk terus mengikuti kegiatan pembelajaran. Sebagaimana diungkapkan bahwa pendidikan jasmani yang diselenggarakan di sekolah pada dasarnya memiliki tujuan untuk meningkatkan kebugaran jasmani keterampilan peserta didik dalam berolahraga, meningkatkan taraf kesehatan, (Dini Rosdiani, 2012:34).

Melalui proses pembelajaran dan pengembangan pendidikan jasmani disekolah yang dirancang melalui permainan, diharapkan murid-murid dapat memperoleh pengalaman yang erat kaitannya dengan peningkatan gerak baik melalui proses interaksi dengan teman maupun hasil dari proses pembelajaran pendidikan jasmani. Melalui pembelajaran pendidikan jasmani yang tepat, siswa dapat melakukan kegiatan berupa bentuk-bentuk permainan dan olahraga yang disesuaikan atau dikondisikan dengan pertumbuhan dan perkembangan anak. Bentuk- 
bentuk permainan yang dimaksud di atas dapat diambil dari permainan atau olahraga tradisional yang selama ini sudah hampir tidak dimainkan lagi anak-anak sekarang.

Bila melihat metode pembelajaran yang dikembangkan oleh guru pendidikan jasmani di sekolah masih belum memanfaatkan permainan sebagai media pembelajaran di sekolah untuk pencapaian indikator yang ditetapkan dalam satu pokok bahasan pendidikan jasmani, sementara dengan menggunakan permainan murud-murid menjadi senang mengikuti pembelajaran karena sambil bermainan proses belajarmengajar tetap berlangsung indicator pembelajaran juga dapat tercapai.

Pembelajaran Atletik, (lari, lompat dan lempar) bila diamati kurang diminati oleh murid-murid SMA karena tidak dalam bentuk permainan, agar murid-murid dapat menyenangi maka pembelajaran atletik khususnya lari sprint dan lompat jauh sebaiknya dilakukan dalam bentuk permainan, sehingga murid-murid dapat mengikuti pembelajaran sambil bermain, indicator pembelajarah dapat tercapai.

Anak menyukai berbagai cabang olahraga permainan. Keinginan anak untuk menyerap sebanyak mungkin pengetahuan dan keterampilan merupakan bagian dari pertumbuhan dan perkembangan anak yang bersifat alami. Pengetahuan dan keterampilan itu menjadi bekal untuk digunakan pada berbagai situasi yang tepat, (H.Y.S. Santosa Giriwijoyo dan Didik Zafar Sidik, 2012:87). Barkaitan dengan hal di atas maka sangat tepat bila guru penjas menggunakan pendekatan bermain, dalam proses belajar mengajar penjas di sekolah untuk pencapaian indicator pembelajaran.

Berdasarkan permasalahan pada latar belakang, maka penulis mengambil kesimpulan bahwa perlu dilakukan penyuluhan kepada guru-guru pendidikan jasmani tentang pemanfaatan permainan tradisional dalam pencapaian indicator pembelajaran, karena dengan metode tersebut dapat memberikan motivasi murid-murid dalam mengikutu pembelajaran, efektif dalam pencapain indicator pembelajaran serta memberikan kemudahan kepada guru pendidikan jasmani dalam menyampaikan materi pelajaran.

Guru penjas dalam melakukan
proses belajar mengajar memiliki kecenderungan langsung melakukan kegiatan yang mengarah ke pencapaian indicator pembelajaran, sementara murid-murid memiliki kecenderungan untuk bermaian, karena itu guru penjas diharapkan dapat merancang pencapaian indicator pembelajaran melalui permainan yang sesuai dengan indicator yang akan dicapai. Sehubungan dengan hal di atas, maka yang menjadi permasalahan pada kegiatan ini adalah:

a. Bagaimana melakukan pembelajaran penjas dengan menggunakan permainan tradisional untuk pencapaian indicator prmbelajaran.

b. Permainan tradisional apa saja yang dapat digunakan untuk pencapaian indikator pembelajaran keterampilan lari sprint dan kemampuan lompat jauh.

Tujuan kegiatan ini dilakukan kepada guru-guru penjas adalah untuk:

a. Memberikan pemahaman kepada guru penjas tentang bentuk-bentuk permainan tradisional yang dapat digunakan sebagai media pembelajaran untuk pencapaian indicator pembelajaran keterampilan lari sprint dan kemampuan lompat jauh.

b. Memberikan pemahaman kepada guru penjas perlunya melakukan pembelajaran penjas dalam bentuk bermain untuk pencapaian indicator pembelajaran.

\section{METODE PELAKSANAAN}

Kegiatan ini sasarannya adalah guru penjas di Kabupaten Tanjung Jabung Timur, metode pelaksanaan yang digunakan adalah melalui penyuluhan kepada guru penjas dalam rangka peningkatan pengetahuan dan pemahaman tentang upayah pencapaian indicator pembelajaran melalui permainan tradisional, adapun alur atau tahap pelaksanaannya adalah sebagai berikut: 


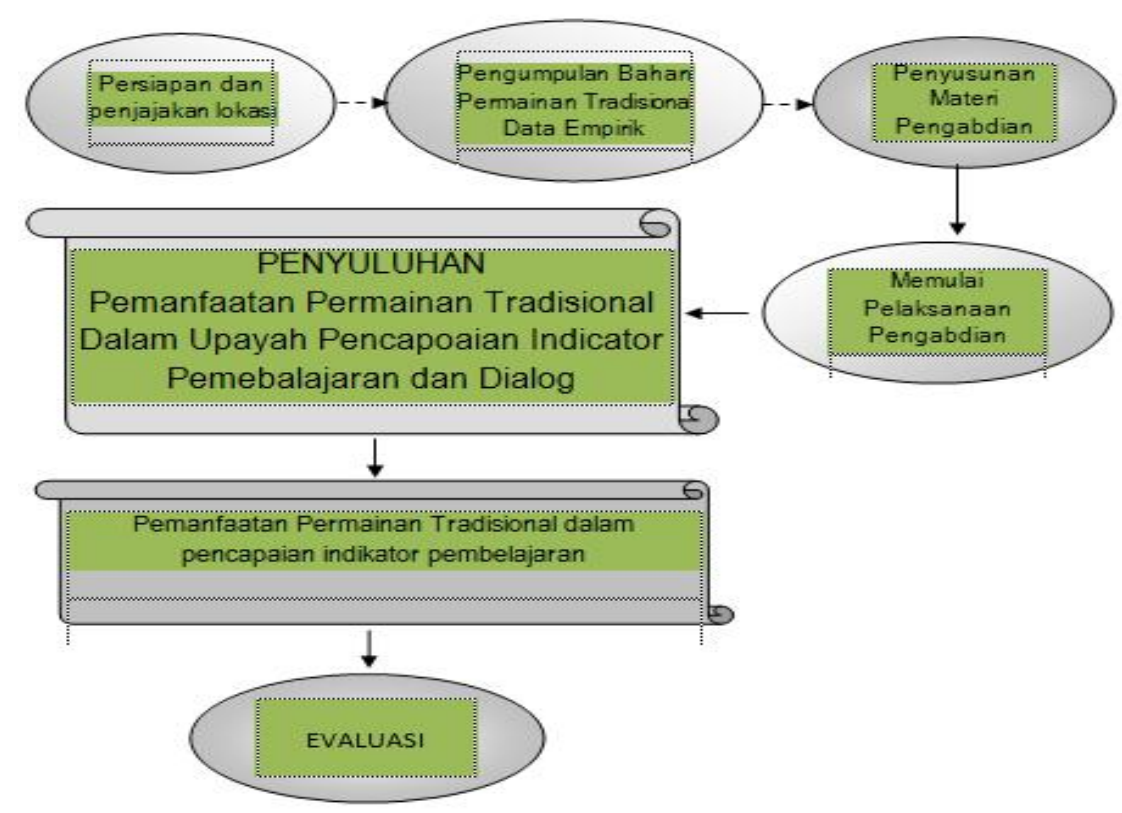

Gambar 1. Tahap Pelaksanaan

Secara ringkas kegiatan pengabdian pada masyarakat dilakukan dengan teknik berikut:

\section{a. Survei Pendahuluan.}

Dilakukan untuk menghimpun persoalan yang dialami oleh guru-guru penjas dalam melakukan proses belajar mengajar dalam upaya pencapaian indicator pembelajaran di wilayah penyuluhan, kemudian melakukan kerjasama dengan SMA Negeri 5 dan SMA Negeri 8 Tanjung Jabung Timur, setelah itu mengumpulkan Guru-guru Penjas Orkes yang berada di Wilayah Kecamatan Muara Sabak Barat, Sabak Timur, Geragai Dan Kecamatan Dendang.

\section{b. Pelaksanaan Kegiatan}

a) Pngenalan beberapa indicator pembelajaran penjas yang dapat dicapai melalui permainan tradisional. Sasaran yaitu Guruguru penjas di Kecamatan Muara Sabak Barat dan Muara Sabak Timur. Tujuannya adar Guru-guru Penjas mengetahui beberapa indikator yang dapat dicapai melalui permainan tradisional

b) Pengenalan beberapa jenis permainan tradisional yang dapat digunakan sebagai media pembelajaran penjas untuk pencapaian indikator pembelajaran. Sasaran yaitu Guru-guru penjas di Kecamatan Muara Sabak Barat dan Muara Sabak Timur. Tujuannya adalah memberikan pengetahuan tentang beberapa bentuk permainan tradisional yang dapat digunakan sebagai media pembelajaran untuk pencapaian indikataor pembelajaran penjas. c) Penyuluhan tentang pelaksanaan permainan tradisional untuk pencapaian indikator pembelajaran penjas. Sasaran yaitu Guruguru penjas di Kecamatan Muara Sabak Barat dan Muara Sabak Timur. Tujuannya adalah peningkatan pengetahuan tentang cara pelaksanaan permainan tradisional untuk pencapaian indikator pembelajaran penjas.

d) Penerapan bentuk permainan tradisional untuk pencapaian indikator pembelajaran disekolah tempat guru mengajar penjas. Sasaran yaitu Guru-guru penjas di Kecamatan Muara Sabak Barat dan Muara Sabak Timur. Tujuannya adalah Peningkatan pengetahuan bentuk permaian tradisional yang dapat digunakan untuk pencapaian indicator pembelajaran penjas yang dilakukanoleh guru penjas

\section{c. Monitoring dan evaluasi}

Setelah seluruh rangkaian kegiatan pengabdian pada masyarakat telah dilaksanakan maka dilakukan evaluasi dan monitoring terhadap penyuluhan yang telah dilakukan, ini dimaksudkan untuk melihat pelaksanaan pembelajaran yang dilakukan oleh guru penjas yaitu dengan cara memanfaatkan permainan tradisional untuk pencapaian indikator pembelajaran yaitu keterampilan lari sprint dan kemampuan lompat jauh.

\section{HASIL \& PEMBAHASAN}


Semakin berkembangnya zaman yang didominasi oleh berbagai macam kecanggihan teknologi, menggeser kesenangan anak-anak pada berbagai macam permainan tradisional. tanpa disadari hal tersebut berpengaruh bagi perkembangan anak-anak yang merupakan generasi penerus bangsa. Permainan tradisional, selain sebagai hiburan dan ajang permainan, ternyata memiliki pengaruh besar terhadap perkembangan anak, salah satunya adalah anak-anak lebih berbahagia, serta memiliki pengalaman masa kecil yang menyenangkan, yang kelak dapat diceritakan pada anak-cucu mereka kelak (http://semuthitampemenang.blogspot.com/ 2013/02/manfaat-permainan-tradisional-bagi. html.). Permainan tradisional adalah permainan yang mengandung unsur-unsur kebudayaan yang tidak dapat dianggap remeh, karena permainan tradisional memberikan pengaruh yang besar terhadap perkembangan kejiwaan, sifat, dan kehidupan sosial anak di kemudian hari. (http:// repository.upi.edu/ operator/upload/s_jkr_0605488_chapter2.pdf.)

Selain itu ungkapan tentang Permainan/olahraga tradisional adalah jenis kegiatan yang mengandung aturan-aturan khusus yang merupakan cerminan karakter dan berasal atau berakar dari budaya asli masyarakat Indonesia". http://repository.upi.edu/operator/upload/s j jkr 0605488 chapter2.pdf.

Permainan tradisional merupakan jenis permainan yang mengandung nilai-nilai budaya, pada hakikatnya merupakan warisan leluhur yang harus dilestarikan keberadaannya. Pada permainan tradisional terdapat bentuk permainan yang sifatnya bertanding (games) dan ada pula yang bersifat lebih mengutamakan untuk mengisi waktu luang sebagai bentuk rekreasi.

Jika diamati dari kreatifitas yang dilakukan anak dalam permainan tradisional mengandung unsur-unsur keterampilan, kecepatan kaki dan tangan, menggunakan kekuatan tubuh, ketajaman penglihatan, kecerdasan pikiran, keluwesan gerak tubuh. (Andang Ismail, 2006:106).

Ungkapan di atas menunjukkan bahwa permainan tradisional cocok digunakan untuk melatih dan sebagai media pembelajaran olahraga karena dapat membentuk keterampilan, kecepatan, kekuatan, kelincahan dan lain sebagainya, bila dilakukan dengan baik dan benar.
Permainan tradisional Indonesian merupakan produk budaya lokal yang tersebar di plosok-plosok. Hal ini mengidentifikasi bahwa Indonesia sangat kaya akan permainan tradisional, namun sayangnya dari sekian banyak permainan tersebut, saat ini keberadaannya sudah sangat sulit ditelusuri dan dilacak, bahkan dapat dikatakan terancam punah. (Dani Wardani, 2009:43) Hal ini dikarenakan ada pergeseran nilai dan zaman, dimana anak-anak Indonesia tidak lagi memainkannya, bahkan tidak mengetahuinya lagi, karena tergeser dari permainan modern yang canggih dan lebih menarik.

Permainan tradisional ada yang sudah dikenal secara nasional dan ada juga yang belum, kategori yang dikenal secara nasional adalah yang tercatat dalam buku-buku dan sudah diterbitkan sedang yang belum adalah permainan tradisional yang masih berada dalam masyarakat dan tidak dicatat dalam buku-buku untuk diterbitkan. Untuk itu, permainan tradisioanal tidak memiliki aturan secara tertulis. Biasanya, aturan yang berlaku, selain aturan yang sudah umum digunakan, ditambah dengan aturan yang disesuaikan dengan kesepakatan para pemain. Di sini juga terlihat bahwa para pemain dituntut untuk kreatif menciptakan aturan-aturan yang sesuai dengan keadaan mereka.

Berikut akan di jelaskan beberapa macam permainan tradisional yang dimainkan oleh siswa dan menurut penulis apa bila dimainkan dapat membentuk keterampilan, kecepatan, kekuatan dan kelincahan, sehingga dapat dijadikan sebagai media pembelajaran penjas untuk meningkatkan kebugaran jasmani, adapun permainan tradisional yang dimaksud adalah:

\section{b. Bentuk-Bentuk Perainan Tradisional yang disampaikan}

Bentuk permainan tradisional yang dapat dimanfaatkan digunakan dalam proses belajar mengajar untuk pencapaaian indicator pembelajaran antara lain:

a) Permainan lari menyentuh tanah

Indicator yang ingin dicapai pada pelaksanaan permainan tersebut yaitu: Teknik Start Berdiri, Keterampilan Berlari, Teknik Melewati Garis Finish, pada pembelajaran lari sprint. Cara pelaksanaan sebagai berikut:

1) Siswa/i dianjurkan membentuk syaf

2) Sepakati aba-aba atau tanda untuk setiap gerakan

3) Misalnya bunyi pluit panjang siswa/i memegang tanah sambil jongkok mempraktikkan gerakan berikut 


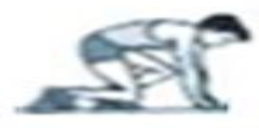

Pada aba-aba (DISEPAKATI) siswa/i mempraktikkan gambar berikut

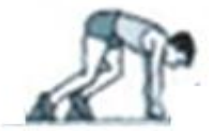

4) Tepukan tangan $1 x$ siswa/i berlari secepatcepatnya mempraktikkan gambar berikut

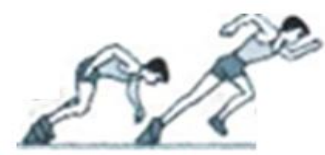

5) Tepukan tangan $2 \times$ siswa/i berhenti langsung jongkok memegang tanah sambil mempraktikkan gambar berikut

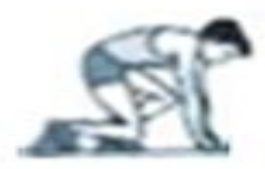

Pada aba-aba siappppp siswa/i mempraktikkan gambar berikut

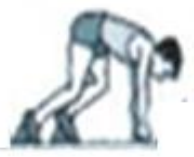

6) Tepukan tangan $1 \times$ siswa/i berlari secepatcepatnya dengan mempraktikkan gambar berikut

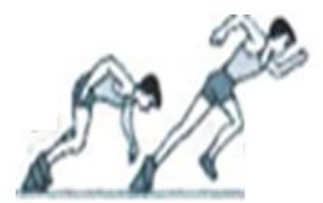

7) Bunyi pluit pendek (ada tanda khusus) saat melewati tanda siswa/i sambil berlari mempraktikkan cara melewati garis finish seperti gambar berikut

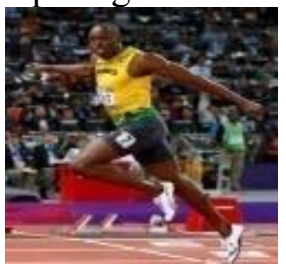

8) Begitu seterusnya lakukan secara berulangulang.

b) Permainan Hitam Hijau

Indicator yang ingin dicapai pada pelaksanaan permainan tersebut yaitu: Lari Sprint: Teknik Start Berdiri, Keterampilan Berlari, Teknik
Melewati Garis Finish. Cara pelaksanaan sebagai berikut:

1) Buat dua garis panjang, jarak antara garis sekita 1,5 meter (sebagai garis start), dibuat juga dua garis sebagai garis finih masingmasing sekitar 10 meter dari garis finish.

2) Siswa/i dianjurkan membentuk dua syaf dan saling berpasangan

3) Siswa/i dianjurkan saling membelakangi

4) Berikan penjelasan yang harus dilakukan oleh siswa/i (aba-aba bersedia, siap, yak) dan saat melewati gari yang telah dibuat (garis finish) siswa/i mempraktikkan cara melewati garis finish

5) Anjurkan untuk saling membelakangi

6) Aba bersedia siswa/i mempraktikkan start jongkok seperti gambar berikut

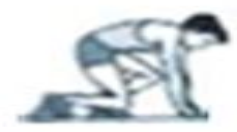

7) Aba-aba siapppp siswa/i mengangkat pinggulnya lebih tinggi dari bahunya seperti gambar berikut

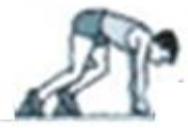

8) Yak siswa/i mengangkat bahu sambil melakukanlari secepat-cepatnya, seperti gambar berikut

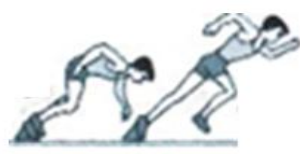

9) Saat melewati garis finish siswa/i mempraktikkan cara melewati garis finis. (membusungkan dada atau bahu kedepan, atau lari terus menerus beberapa meter kedepan), seperti gambar berikut

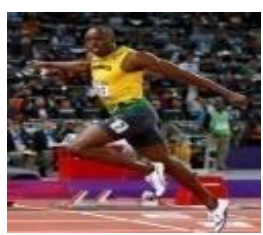

10) Lakukan secara berulang-ulang.

Berikut Gambar lapangan Hitam Hijau 


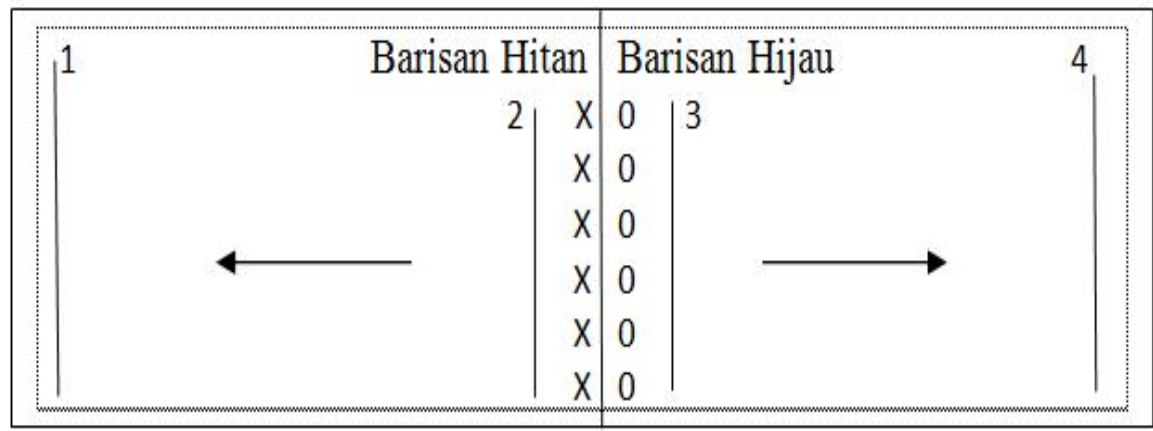

Keterangan gambar di atas

$\mathrm{X}=$ Anggota kelompok barisan hitam

0 = Anggota kelompok barisan hijau

$\longrightarrow=$ Arah Lari saat dikejar anggota kelompok barisan hijau

$\longleftarrow \quad=$ Arah Lari saat dikejar anggota kelompok barisan hitam

No. $1=$ Garis finis pada daerah Hitam

No. $2=$ Garis star pada daerah Hitam

No. $3=$ Garis star pada daerah Hijau

No. 4 = Daris finis pada daerah Hijau

\section{c) Permainan Sentuh Batu}

Indicator yang ingin dicapai pada pelaksanaan permainan tersebut yaitu: Lari Sprint: Teknik Start Berdiri, Keterampilan Berlari, Teknik Melewati Garis Finish. Cara Pelaksanaan sebagai berikut:

1) Lakukan Pembagian anggota regu (diharapkan jumlahnya sama)

2) Meletakkan kedua batu yang harus dijaga oleh masing-masing regu.

3) Melakukan undian untuk menentukan regu yang akan terlebih dahulu salah satu teman satu regunya meninggalkan batunya untuk dikejar.

4) Setelah diundi permainan dimulai (masingmasing regu berkerumun menginjak batunya).

5) Setelah dimulai, regu yang telah ditetapkan salah satu temannya pertama kali meninggalkan batunya segera meninggalkan batunya (mendekati batu lawan) namun mereka harus menjaga agar tidak tertangkap oleh pihak lawan sambil memancing pihak lawan untuk mengejarnya.

6) Pihak lawan harus mengejar, yang mengejar boleh 1 (satu) orang atau lebih (namun harus tetap ada yang menjaga batu) dan yang mengejar berusaha menangkap yang dikejar tersebut, pihak yang dikejar berlari secara bebas (sebatas lapangan yang telah ditepkan) namun boleh juga lari kembali ke batunya bergabung dengan kelompoknya yang menunggu batunya untuk menghindari tangkapan lawan.

7) Saat temannya dalam satu regu yang dikejar, teman yang lain boleh membatu dengan cara mengejar lawan yang mengejar temannya tersebut dan berusaha menangkapnya. Karena ada yang membantu maka pihak yang mengejar tersebut berusaha agar tidak tertangkap oleh regu yang membantu temannya dan sebaiknya berlari kembali bergabung dengan temannya yang berkumpul menginjak batunya. Begitulah seterusnya saling mengejar.

8) Apa bila dalam pelaksanaan saling mengejar ada yang tertangkap maka yang tertangkap, maka mereka akan menjadi tawanan lawan dan berdiri 1,5 meter dari batu lawan (makin banyak tertangkap makin bagus), yang tertangkap bisa bergabung dengan temannya lagi apa bila ada teman dalam satu regu yang datang mengambil mereka, namun tidak mudah karena regu lawan menjaga tawanan tersebut.

9) Poin diperoleh apa bila salah satu anggota regu ada yang berhasil menyentuh batu dengan kaki yang dijaga oleh regu pemilik batu.

10) Kemungkinan untuk mendapatkan poin apa bila salah satu regu banyak yang tertangkap sehingga batu yang dijaga oleh regu yang banyak ditangkap temannya bisa 
dikepung dan ramai-ramai menyentuh batu dengan menggunakan kaki, (setiap menyentuh batu poin yang diperoleh hanya 1 (satu) walaupun saat dikepung ramairamai menyentuh batu.

11) Pada saat ada salah satu anggota regu yang berhasil menyentuh batu maka permainan kembali seperti awal yaitu semua anggota regu berkumpul kembali di batunya masing-masing, dan memulai kembali permainan seperti awal.

12) Pemenangnya adalah regu yang berhasil mengumpulkan poin lebih banyak.

13) Ketentuan: pemain yang terlebih dahulu meninggalkan batunya itu yang berhak ditengkap.

Berikut gambar lapangan permainan tradisional sentuh batu:

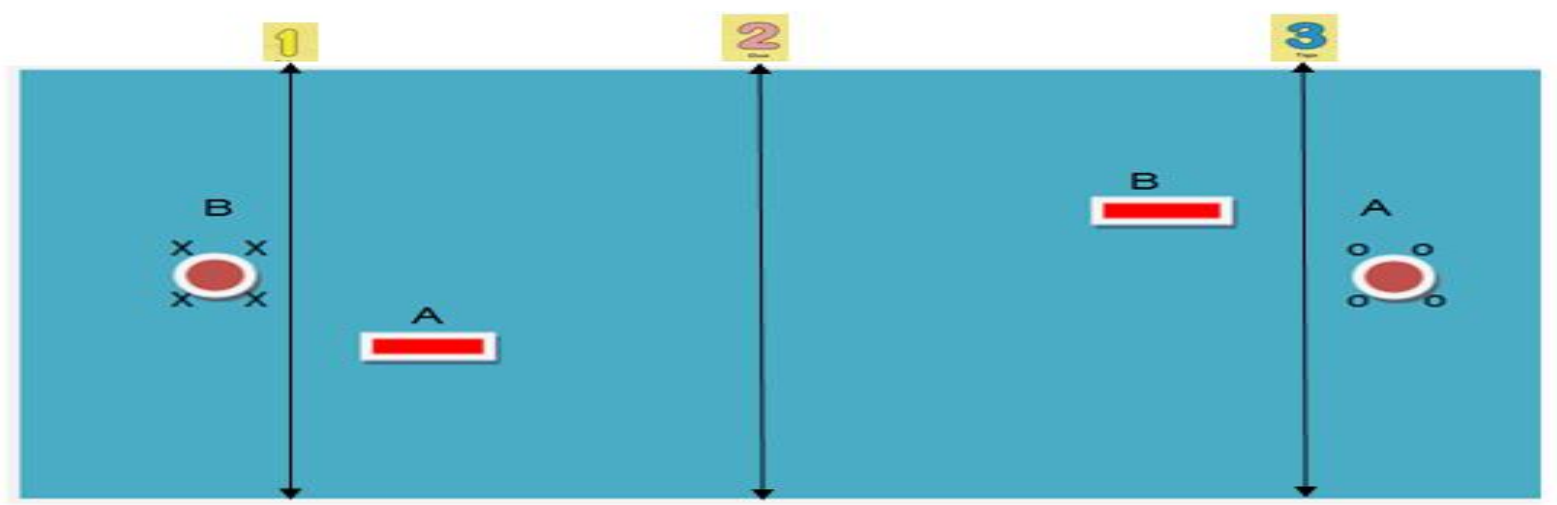

Gambar: Lapangan Permainan Sentuh Batu.

Sumber : A Husna M. (2009 : 33).

\section{Keterangan Gambar di atas}

$\mathrm{X}=$ Anggota regu $\mathrm{B}, 4$ orang

$\mathrm{O}$ = Anggota regu A, 4 Orang

= Batu yang harus dijaga (1,5 meter dari garis pinggir)

$=$ Tempat anggota regu yang di tangkap (1,5 meter dari batu)

$=$ Area untuk saling mengejar (ukuran $15 \times 10$ meter)

1, 2, 3 = 1 (Garis Star B), 2 (Garis Finish), 3 (Garis Star A)

\section{d) Permainan Batang Lidi}

Indicator yang ingin dicapai pada pelaksanaan permainan tersebut yaitu: Kemamp[uan Power Tungkai, Kemampuan lompat jauh, Cara Pelaksanaan sebagai berikut:

1) Siapkan dua batang lidi (atau sejenisnya) kira $\pm 1,5 \mathrm{~s} / \mathrm{d}$ 2meter, seperti gambar berikut:

2) Buat Garis berbentuk segi empat sebagai tempat tumpuan seperti gambar berikut:

3) Letakkan lidi atau sejenisnya di depan garis yang telah di buat seperti gambar berikut:

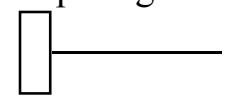

4) Ambil awalan dan lakukan berlari sambil melompat seajuh-jauhnya melewati lidi yang telah diletakkan tersebut (diharapkan menumpuh pada garis berbentuk segi empat dan mendarat di ujung lidi), seperti gambar berikut:

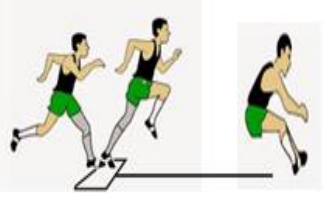

5) Ambil lidih yang sudah dilewati tersebut kemudian pindahkan di depan tempat mendarat tersebut, seperti gambar berikut:.

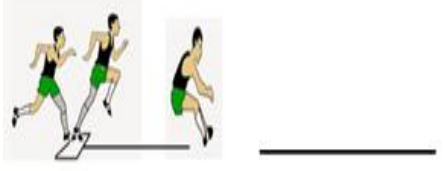

6) Lanjutkan melompat dengan tumpuan dua kaki atau satu kaki ke ujung lidi yang telah diletakkan di depan tempat mendarat tersebut, seperti gambar berikut: 


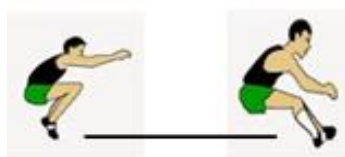

7) Begitulah seterusnya.

\section{KESIMPULAN \& SARAN}

1) Dalam upaya pencapaian indicator pembelajaran atletika dapat dilakukan dengan menggunakan metode permainan tradisional.

2) Pemanfaatan permainan tradisional dalam upayah pencapaian indicator pembelajara belum dilakukan oleh para guruh Penjas Orkes di Kabupaten Tanjung Jabung Timur.

3) Pemanfaatan permainan tradisional dalam upayah pencapaian indicator pembelajara harus dirancang sedemikian rupa sehingga sesuai dengan materi pembelajaran.

\section{Saran}

1) Disarankan kepada Guru Penjas Orkes agar mencari bentuk permainan untuk dimanfaatkan dalam proses belajar mengar dalam upaya pencapaian indicator pembelajaran.

2) Disarankan kepada Guru Penjas Orkes agar mengunakan bentuk-bentuk permainan dalam upayah pencapaian indicator pembelajaran.

3) Disarankan kepada Guru Penjas Orkes, agar siswanya senang mengikuti pembelajaran atletik hendaknya menggunakan permainan dalam proses belajar mengajar.

4) Disarankan kepada pembuat kebijakan agar memasukkan permainan tradisional kedalam kurikulum sebagai media pembelajaran untuk pencapaian indicator pembelajaran.

\section{DAFTAR PUSTAKA}

A. Husna M, 2009. 100+Permainan Tradisional Indonesia, untuk kreativitas, Ketangkasan, dan Keakraban, Yogyakarta, Andi Offset.

Dikdik Zafar Sidik, 2011. Mengajar dan Melatih Atletik (Bandung: PT. Remaja Rosdakarya offset.

Dini Rosdiani, 2012. Model Pembelajaran Langsung dalam Pendidikan Jasmani dan Kesehatan, Bandung: ALPABETA.

H.Y.S. Santosa Giriwijoyo dan Didik Zafar Sidik, 2012, Ilmu Kesehatan Olahraga, Bandung P.T. Remaja Rosdakarya Offset.
Undang-undang Republik Indonesia Nomor 20 tahun 2003, tentang Sistem Pendidikan Nasional, Bab II, Pasal 3.

Undang-undang Republik Indonesia nomor 3 tahun 2005, tentang Sistem Keolahragaan Nasional, pada Bab VI pasal 18 ayat 8 .

Undang-undang Republik Indonesia Nomor 14 tahun 2005, tentang Guru dan Dosen

W.S, Winkell. 2001 Psikologi Pengajaran. (Yogyakarta: PT. Gramedia 